Chapman University

Chapman University Digital Commons

Education Faculty Articles and Research

College of Educational Studies

1988

\title{
Culture or Canon? Critical Pedagogy and the Politics of Literacy
}

Peter McLaren

Chapman University, mclaren@chapman.edu

Follow this and additional works at: http://digitalcommons.chapman.edu/education_articles

\section{Recommended Citation}

McLaren, P. (1988). Culture or canon? Critical pedagogy and the politics of literacy. Harvard Educational Review, 58(2): 213-234.

This Book Review is brought to you for free and open access by the College of Educational Studies at Chapman University Digital Commons. It has been accepted for inclusion in Education Faculty Articles and Research by an authorized administrator of Chapman University Digital Commons. For more information, please contact laughtin@chapman.edu. 


\section{Culture or Canon? Critical Pedagogy and the Politics of Literacy}

\section{Comments}

This review was originally posted in Harvard Educational Review, volume 58, issue 2, in 1988.

\section{Copyright}

Harvard Education Publishing Group 


\title{
Culture or Canon? Critical Pedagogy and the Politics of Literacy
}

\author{
PETER L. MaLAREN, Miami University, Ohio
}

Literacy: Reading the Word ANd the WORLd

by Paulo Freire and Donaldo Macedo.

South Hadley, MA: Bergin E̊ Garvey, 1987. 184 pp. \$12.95 (paper).

A major debate has emerged in the United States over the questions of what constitutes literacy, who has access to it, and what values and practices are legitimated by it. The parameters of this debate are no longer constrained by what it means to be occupationally literate; rather, the more pressing question today is what kind of knowledge learners must acquire in order to participate in society as active, informed citizens. Literacy has ceased to be treated solely as a technical discourse for entrance into the world of work. In fact, the use of the term has changed dramatically in recent years. Once restrictively defined as providing students with specific technical skills related to reading, writing, and speaking, the term literacy has also come to mean educating students to be culturally literate; that is, to be bearers of certain meanings, values, and views.

That the concept of literacy has entertained nearly constant debate during recent years is not surprising, given the various reactions to current reform efforts which are attempting to bring "excellence" back to American education. In addition to generating antipathy among various groups of critics, these efforts have yielded to an inexorable process of narrowing and technicizing the concept of literacy. Within the last decade three positions have come to characterize the politics and pedagogy of literacy. These positions generally break down into the following: functional literacy, cultural literacy, and critical literacy. Functional literacy refers primarily to the technical mastery of particular skills necessary for students to decode simple texts such as street signs, instruction manuals, or the front page of a daily newspaper. Definitions of functional literacy vary, but generally include the ability to read somewhere between the fourth- and eighth-grade levels on standardized reading tests. ${ }^{1}$ Cultural literacy refers to the acquisition of a broad range of factors which accompany functional literacy, such as a familiarity with particular linguistic traditions or bodies of information. More specifically, it means acquiring a knowledge of selected works of literature and historical information necessary for informed participation in the political and cultural life of the nation. Two radically different positions characterize cultural literacy. The first advances the establishment of a cultural index or a cultural canon of literary works pre-

\footnotetext{
${ }^{1}$ If one defines illiteracy as being able to read only the simplest texts and street signs, then about 27 million adults would be considered illiterate. If one includes the ability to read the local newspaper or articles in digest magazines, then about 45 million adults would be classified as illiterate. If the standards are closer to a high school level, then 72 million Americans would be classified as illiterate. Adults who are functionally literate read somewhere between fourth- and eighth-grade levels. See Jeanne S. Chall, Elizabeth Heron, and Ann Hilferty, “Adult Literacy: New and Enduring Problems," Phi Delta Kappan, 69 (1987), 190-196.
}

Harvard Educational Review Vol. 58 No. 2 May 1988

Copyright $(\subset$ by President and Fellows of Harvard College $0017-8055 / 88 / 0500-0213 \$ 01.25 / 0$ 
scribed for all students and also insists upon a required form of English usage; the second advocates using the language standards and cultural information students bring into the classroom as legitimate and important constituents of learning. Critical literacy, on the other hand, involves decoding the ideological dimensions of texts, institutions, social practices, and cultural forms such as television and film, in order to reveal their selective interests. The purpose behind acquiring this type of literacy is to create a citizenry critical enough to both analyze and challenge the oppressive characteristics of the larger society so that a more just, equitable, and democratic society can be created. Each of these perspectives on literacy has its exponents, proponents, and detractors; and each category has become a buzzword in the lexicon of the current debate over excellence in education.

\section{Functional Literacy}

Recent revelations by Jonathan Kozol and others that the functionally and marginally illiterate population of the United States may now exceed 60 million has provoked widespread concern both in the public domain and across the educational system. ${ }^{2}$ While this estimate has been the focus of some dispute among literacy researchers, it remains the case that only about 4 million adults nationwide are being helped through currently available literacy programs, including volunteer programs (such as Literacy Volunteers of America and Laubach Literacy Volunteers) as well as competency-based and community-based programs. ${ }^{3}$ Together, all federal, state, municipal, and private literacy programs in the United States reach a maximum of 4 percent of the illiterate population. ${ }^{4}$ In an even less salutary light, the current literacy crisis has helped heighten the moral panic - no doubt fueled by a growing xenophobia - surrounding the rapidly expanding Hispanic population. A movement is now in progress, headed by former California senator S. I. Hayakawa, to devalue bilingual education programs and to make English the official language of the United States.

Mainstream theories of literacy conceive of being literate as possessing only that requisite fund of knowledge - that privileged form of linguistic currency-necessary for students to succeed materially in an industrialized capitalist society. This perspective still informs most school-based literacy programs across the United States. In this view, the nonstandard literacies of minority groups and the poor (that is, different dialects, nonstandard English) are regarded as deficits or deprivations rather than differences. Some research suggests that many of today's illiterates are dropouts of reading programs that demand strongly analytic/auditory reading styles as distinct from whole-language approaches to teaching reading. ${ }^{5}$

\footnotetext{
${ }^{2}$ Jonathan Kozol, Illiterate America (New York: Anchor Press/Doubleday, 1985), p. 4.

${ }^{3}$ Chall, Heron, and Hilferty, "Adult Literacy," p. 192. For a comparison between the Laubach and Freirean approaches, see Michael Holzman, "A Post-Freirean Model for Adult Literacy Education," College English, 50 (1988), 177-189.

${ }^{4}$ Kozol, Illiterate America, p. 5.

5 Marie Carbo, "Deprogramming Reading Failure: Giving Unequal Learners an Equal Chance," Phi Delta Kappan, 69 (Nov. 1987), 197-202. Colin Lankshear has undertaken an excellent critique of literacy programs based on the model of functional literacy. Lankshear claims that conventional models of functional literacy are actually dysfunctional for the disadvantaged illiterate adult and functional for those whose interests are best served by maintaining the economic, political, and cultural status quo. His radical alternative model of functional literacy is very similar to the position of critical literacy, although Lankshear prefers to keep the term "functional literacy" because it enjoys widespread
} 


\section{Cultural Literacy}

Although approaches to literacy continually suffer the conflictual relationships of opposing groups and theoretical perspectives, a more critical consensus on what literacy means is beginning to take shape. Theorists are starting to acknowledge the difficulty in separating cultural literacy from reading and writing in general. In fact, some argue that reading and writing are relatively futile and empty exercises unless accompanied by at least some form of cultural knowledge. ${ }^{6}$ For example, Ivan Illich has recently begun to theorize about the relationship between "scribal literacy," the ability to read and write, and "lay literacy," the set of pervasive competencies and cultural knowledge that is required to participate in a literate society. ${ }^{7}$

In her 1985 American Educational Studies Association Butts Lecture entitled "Literacy and Learning in the Making of Citizens," Shirley Brice Heath emphasizes the indissoluable link between literacy, context, and meaning. She notes:

Unless accompanied with cultural knowledge, personal drive, political motivation, or economic opportunity, literacy does not lead the writer to make the essential leap from literacy to being literate-from knowing what the words say to understanding what they mean. Readers make meaning by linking the symbols on the page with real-world knowledge and then considering what the text means for generating new ideas and actions not explicitly written or "said" in the text. The transformation of literacy skills into literate behaviors and ways of thinking depends on a community of talkers who make the text mean something. For most of history, such literate communities have been elite groups, holding themselves and their knowledge and power apart from the masses. ${ }^{8}$

Among the exponents of "cultural literacy," two polar positions seem apparent that reflect both liberal and conservative orientations in the cultural literacy perspective. The "prescriptivists" argue that students' success in the North American marketplace depends upon their successful entrance into the academy. This generally means being taught from a prescribed canon of literary works and acquiring a standard form of English. The "pluralists," on the other hand, argue for the legitimacy of a broader range of discursive practices which reflect more closely the language practices, values, and interests of racially and economically diverse groups of students. ${ }^{9}$ The pluralists attempt to affirm and legitimize the cultural universes, knowledge, and language practices that students bring into the classroom. Both these orientations reflect an understanding of literacy which incorporates, along with the mastery of technical skill, the explicit recognition of the importance of some form of shared cultural knowledge.

support and financial affirmation. Based on the ideas of Freire, Lankshear's model is grounded in a dialectic between literacy and empowerment that is linked to a transformation of dehumanizing social structures. See Colin Lankshear, "Humanizing Functional Literacy: Beyond Utilitarian Necessity," Educational Theory, 36 (1986), 375-387.

"Shirley Brice Heath, "Literacy and Learning in the Making of Citizens," 1985 Butts Lecture. In Civic Education, Pluralism and Literacy, published jointly by AESA News and Comment and The Center for the Studies of Citizenship and Public Affairs, Syracuse University, August, 1986, p. 16.

7 Ivan Illich, "A Plea for Research on Lay Literacy," Interchange, 18 (1987), 9-22.

${ }^{8}$ Heath, "Literacy and Learning," p. 16.

9 Patricia Bizzell, "Cultural Literacy," unpublished paper. I am greatly indebted to this paper for providing me with some of the primary categories used in my analysis. A published version of this paper has recently appeared. See Patricia Bizzell, "Arguing about Literacy," College English, 50 (1988), 141-153. 
Figures most frequently associated with the recent debate over "what every American needs to know"-E. D. Hirsch, Allan Bloom, and Secretary of Education William J. Bennett-have raised the stakes appreciably with respect to the kind of knowledge students should be taught, and in what manner. ${ }^{10}$ Their widely publicized positions on literacy and the virtues of higher learning focus directly on which knowledge should be dispensed to students, which virtues should be reflected in student character and behavior, and who should be the credentializing agents for this process. Bennett's ideological recipe for a national curriculum reflects the positions of both Hirsch and Bloom. In his attack on the fragmented curriculum, Hirsch argues for cultural uniformity-a "traditional literate culture" consisting of a common prescribed content which will supposedly give students access to mainstream economic and political life (and thus by implication become a key avenue to social and economic justice for minority students).

Bloom's concept of literacy is more sweeping. Unlike Hirsch, who incorporates information from both mainstream and elite cultures, Bloom seeks to instill, among the worthiest of students, high-status knowledge based on Platonic principles and virtues which treat knowledge as pristine, transhistorical, universal, and context free. What Hirsch, on the other hand, would like to prescribe for present and future generations of students (despite his claim to be a "descriptivist" and not a "prescriptivist") is cultural information based on some 4,700 items which include facts, dates of battles, authors of books, figures from Greek mythology, and the names of past presidents of the United States. These qualify not so much as information from elite culture but as items familiar to "literate" Americans, although authorities may cavil with respect to which particular pieces of information should be included in Hirsch's index.

While the work of Hirsch and Bloom contains many ideological affinities, it is as difficult to imagine what a common curriculum would look like based on their writings as it is to imagine the game of Trivial Pursuit being played in Plato's Republic. What the work of Hirsch and Bloom means for prescriptivists like Bennett is first of all specifying the shared prior knowledge necessary for students to succeed in the discourse community of literate Americans (for Bloom this becomes the discourse community within the hallowed halls of the academy) and then developing a pedagogical strategy for teaching this knowledge (preferably codified in texts) prescriptively to those who are assumed to be culturally deficient. The prescriptivists' call for a nationally endorsed cultural canon - a "republic of letters" of sorts that would be capable of encoding our culture with a selective history, world view, and epistemology - is tantamount to calling for the construction of a national identity.

${ }^{10}$ The works of these individuals include E. D. Hirsch, Jr., "Restoring Cultural Literacy in the Early Grades," Educational Leadership, 45 (December 1987/January 1988), 63-70; E. D. Hirsch, Jr., Cultural Literacy: What Every American Needs to Know (New York: Houghton Mifflin, 1987); E. D. Hirsch, Jr., "Cultural Literacy," American Scholar, 52 (1982-83), 159-169; E. D. Hirsch, Jr., "Culture and Literacy," Journal of Basic Writing, 3 (1980), 27-47; E. D. Hirsch, Jr., The Philosophy of Composition (Chicago: University of Chicago Press, 1977); Allan Bloom, The Closing of the American Mind: How Higher Education Has Failed Democracy and Impoverished the Souls of Today's Students (New York: Simon \& Schuster, 1987); and the views of William Bennett, which were published when he was chairman of the National Endowment for the Humanities and which were summarized in "'To Reclaim a Legacy': Text of Report on Humanities in Education," Chronicle of Higher Education, November 28, 1984, pp. 16-21. Closely resembling Bennett's view on cultural literacy is What Do Our 17-Year-Olds Know? (New York: Harper \& Row, 1988), written by Diane Ravitch and Chester Finn, Jr., which follows the lead of E. D. Hirsch in substituting the mindless teaching of skills with the mindless teaching of content. See also the review by Deborah Meier and Florence Miller in The Nation, January 9, 1988, pp. 25-27. 
Accordingly, students become accredited as culturally literate to the degree that they accept this national identity inscribed on the tablet of Western high culture.

\section{Critical Literacy}

Lately some participants in the literacy debate have become critical of the prevailing conceptualizations of what it means to be literate and have begun vigorously to challenge the previously sacrosanct positions. These critics are not the inevitable dissenting minority in any discipline but include many recognized leaders in the field, such as Paulo Freire, Harvey Graff, Kenneth Goodman, Yetta Goodman, and Henry Giroux. As the theoretical limitations of the old functional and cultural literacy models become more evident, the focus on formal standards of English is giving way to an exploration of the social construction of knowledge and the ideological processes involved in the reading of texts. In recent years literacy critics have become much more aware of the centrality of "relations of power" to the domain of literacy, which would not normally have been included under the rubric of conventionally defined "politics." What this suggests is that if the process of becoming literate is, in large part, a struggle for voice and the reclamation of one's history, then there is also a critical sense in which literacy itself must be politically defined. ${ }^{11}$

At a time when popularizers of cultural literacy are prescribing a literary canon to pry open the "closed minds" of an American youth putatively on the path to intellectual and moral decline, radical critics, armed with a welter of ethnographic evidence, are attempting to draw our attention to the gendered, racial, and socioeconomic contexts of literacy and the challenge that these new conceptualizations represent. ${ }^{12}$ This challenge, which is presently being undertaken on the dual fronts of pedagogy and popular culture, has manifested itself as a struggle over what counts as legitimate educational knowledge, who has the power to define it as such, and the instructional means by which it should be taught to learners.

\footnotetext{
${ }^{11}$ Simply labeling one in five American adults functionally illiterate masks the fact that a large proportion of these individuals are not fluent in English, and that more than half of them are women. Literacy in this view is treated as though it occurs in a vacuum. Kathleen Rockhill writes that mainstream literacy programs, which emphasize reading and writing in the dominant language, conceal under the banner of equality the ethnocentrism, racism, and sexism inherent in literacy policies. Thus, the presumed neutrality of becoming literate enshrouds the interests of entrenched groups. Rockhill reports that within most literacy approaches learners are treated as the same, but symbolically are dichotomized as literate or illiterate - that is, learners or non-learners - and literacy is established as an isolated, measurable, uniform "thing," a skill or commodity that can be acquired if one only has the necessary motivation to participate in learning opportunities or literacy programs. That is, literacy is treated as though it is outside the social and political relations, ideological practices, and symbolic meaning structures in which it is embedded. See Kathleen Rockhill, "Gender, Language and the Politics of Literacy," British Journal of Sociology of Education, 8 (1987), 153-167. See also Kathleen Rockhill, "Literacy as Threat/Desire: Longing to be SOMEBODY," unpublished paper.

${ }^{12}$ Many important advances in the field of literacy over the last decade have been achieved primarily by researchers working in discourse linguistics and the ethnography of communication. As a result of their efforts, it has become clear that educators can no longer ignore the gap between formal school literacy and the oral tradition of the student's family, home, and community. See J. Cook-Gumperz, ed., The Social Construction of Literacy (London: Cambridge University Press, 1986); Adrian T. Bennett, "Discourses of Power, the Dialectics of Understanding, the Power of Literacy," Journal of Education, 165 (1983), 53-64; and Michelle Sola and Adrian T. Bennett, "The Struggle for Voice: Literacy and Consciousness in an East Harlem School," Journal of Education, 167 (1985), 88-110. See also James Donald, Language, Literacy and Schooling (London: Open University Press, in press).
} 
Those who argue for critical literacy maintain that an uncritical enthusiasm for making individuals functionally literate conceals the substantive issue of what it means to be truly literate behind the imperatives of linguistic mastery. To couch the process of literacy mainly in terms of linguistic competency is to remove the process from the varied context in which literacy is achieved-a context that includes the experiences students bring to the reading act, as well as the contingencies of history, culture, and politics. Exponents of critical literacy generally regard the prescriptivist models of cultural literacy to be a form of cultural imposition undertaken by the guardians of academic discourse communities and the dominant social classes with which they are associated. Advocates of critical literacy avoid espousing a view of cultural knowledge in which meaning derives from a unitary and fixed essence-inherited knowledge and formulations which have been sedimented by the impersonal force of history into the wisdom of the ages. Rather, they conceptualize the production of cultural knowledge as a struggle over competing discourses, the history of which has been swathed in ambiguities and contradictions. In this view, the value of cultural and literary texts resides not in their collective currency as the heralded virtues of society or disinterested ideals of truth, but in the manner in which they have been constructed out of a web of relationships shaped by different gendered, racial, economic, and historical contexts. It is wrong to assume that individual women and men from different social classes read texts in a similar manner, just as it is wrong to assume that the context of reading a work of literature remains undifferentiated through time. As historically produced subjects, readers of texts are governed by different social and ideological formations which may or may not correspond to the formations present when the text was originally produced. Critical literacy focuses, therefore, on the interests and assumptions that inform the generation of knowledge itself. From this perspective all texts, written, spoken, or otherwise represented, constitute ideological weapons capable of enabling certain groups to solidify their power through acts of linguistic hegemony. This can be seen in the ways in which mainstream schooling has stressed the cultural capital of certain speech communities that make up the dominant culture. It is to the issue of the school's complicity in maintaining a "culture of silence" in which inequality is produced among groups on the basis of race, class, and gender that the work of Paulo Freire becomes so significant for American audiences.

\section{Critical Literacy: A Freirean Perspective}

Literacy: Reading the Word and the World is the third book by Paulo Freire to appear in the United States in the past three years. It is the second book translated by, and with the participation of, Donaldo Macedo, although Macedo's contribution is much greater in the present book.

Freire's work has become almost synonymous with the project of literacy. Born in 1921 in Recife, Brazil, a large port city and capital of the northeastern state of Pernambuco, Freire spent his early life in poverty, as underdevelopment and worldwide economic crisis of 1929 saw his family lose its middle-class status and be forced into poverty. Experiencing firsthand the listlessness and apathy of the poor, Freire soon realized that the education system was a primary vehicle in maintaining this "culture of silence." Dedicating his life to the struggle against poverty, Freire spent nearly three decades exploring how the culture and consciousness of illiterate peasants have been shaped by the language and values of the "colonizer," or the dominant culture. 
As Professor of History and Philosophy at the University of Recife in the early 1960 s, Freire worked with peasants in the Brazilian Northeast during that country's national literacy campaign. At that time he evolved a theory of literacy which is based on the conviction that every human being is capable of critically engaging the world in a dialogical encounter with others. In 1964 Freire was arrested, jailed, and later sent into exile after the military seized control of the Brazilian government. His theory of literacy and empowerment culminated in 1970 in the release of his now classic treatise, Pedagogy of the Oppressed, which stressed building upon the learners' indigenous language as the basis for developing reading and writing. Subsequent years were tumultuous and productive: a five-year stay in Chile as a UNESCO consultant with the Agrarian Reform Training and Research Institute in programs for adult education; an appointment in 1969 as Fellow of Harvard University's Center for the Study of Development and Social Change; a move to Switzerland in the same year as consultant and Special Advisor in Education to the Office of Education of the World Council of Churches, where he developed literacy programs for Tanzania and Guinea-Bissau; and the establishment of the Instituto de Acción Cultural in Geneva. Freire's influence was strongly felt in the literacy campaigns of Nicaragua, Cuba, Portugal, Chile, and Angola.

Today his influence extends beyond the domain of literacy and includes developments in social work, education, sociology, participatory research, and critical pedagogy. Freire returned to Brazil in June of 1980, after an amnesty was declared in 1979. He is now Professor of Philosophy of Education at the Pontifícia Universidade Católica de São Paulo and the public Universidade de Campinas in São Paulo.

The participation of Donaldo Macedo, a Cape Verdean-born sociolinguist who now teaches in the Department of English at the University of Massachusetts at Boston, brings a complementary and critical voice both to the theoretical and practical aspects of Freirean pedagogy. In particular, Macedo's familiarity with the critical sociological tradition in education helps to clarify some of Freire's positions on the pedagogical implications and applications of his work. In addition, Macedo's own brand of radical educational politics assists in both situating and extending the more recent advances of Freire's work within the critical educational tradition in the United States.

Ann Berthoff's pithy foreword provides an illuminating discussion of the philosophical roots of Freire's pedagogy, which she terms "a pedagogy of knowing." Following this is a theoretically detailed preface by Henry A. Giroux, which could have functioned equally as an afterword, since it extends many of the ideas discussed throughout the book. A longtime exponent of Freire's work in the United States, Giroux establishes a critical context that provides an invaluable conceptual basis for engaging the text. He provides readers with three primary - and in many ways original-categories for approaching the concept of literacy: literacy as cultural politics; literacy as liberating remembrance; and literacy as narrative.

Giroux's use of the category "cultural politics" draws attention to the social, cultural, political, and economic dimensions of everyday life and illustrates how these must become the major contexts for both language acquisition and usage. The concept of "liberating remembrance" highlights the fundamental importance of history to the process of becoming critically literate. History, argues Giroux, can provide educators with the possibility of establishing both a referent for and a critique of injustice and oppression. Critical readings of history can enable students to recover and reconstruct the "radical potential of memory," investigating historical sources of human suffering so that they can never be repeated. Such "liberat- 
ing remembrance" will also enable the educator to seize whatever images of hope these events might offer to the present. Giroux's third category-literacy as a form of narrative-draws attention to the fact that literacy is always about somebody's story. As a story by somebody and for somebody, knowledge is invariably informed by a set of underlying interests that structure how a particular story is told through such factors as the organization of knowledge, social relations and cultural values, reader reception, and forms of assessment. As a form of narrative, critical literacy becomes a struggle over whose "stories" will prevail as a legitimate object of learning and analysis. The conceptual framework Giroux provides helps to enlarge the range of critical possibilities for examining Freire and Macedo's work.

The book itself takes a somewhat disjointed form: three extensive dialogues between Macedo and Freire; a letter written by Freire to Mario Cabral, Minister of Education of Guinea-Bissau; a portion of the texts of Practice to Learn and other workbooks prepared for the "Culture Circles" of São Tomé and Principe; two essays by Freire; and an essay coauthored by Freire and Macedo. The generative themes involve the act of reading, an updated version of a previously published article; adult literacy and popular libraries, adapted from a talk Freire presented at the Eleventh Brazilian Congress of Library Economy and Documentation in 1982; rethinking literacy, which takes the form of a dialogue between Freire and Macedo; literacy in action, a detailed and practical exposition by Freire of his "Popular Culture Notebooks"; a critical exchange between Freire and Macedo to clarify Freire's controversial involvement in the literacy campaign in GuineaBissau; a dialogue between Freire and Macedo on literacy in the United States; and a coauthored essay in which Freire and Macedo link the concept of literacy to that of critical pedagogy.

Positioning Freire and Macedo's work within the foregoing perspectives on literacy highlights some of the problematic assumptions which inform them. Moreover, it sheds some critical light on current approaches in the United States designed to rescue the nation's "illiterates" through the establishment of a requisite cultural knowledge for all who wish to participate as American citizens. A frequently enunciated thesis of Freire and Macedo states that approaches to literacy, regardless of the country in which they take place, must constitute more than simply the "alphabetization" of the so-called illiterate student. That children have linguistic and communicative skills outside the school which often go unrecognized in the classroom is the first consideration that must be addressed in any critical literacy program. No text can be taught to students in antiseptic isolation from their life and culture. Freire underscores this point when he remarks:

If adult literacy was once treated and realized in an authoritarian way, centered on the magical understanding of the word, a word bestowed by the educator on the illiterate, and if the texts generally offered students once hid much more than they revealed of reality, now literacy as an act of knowledge, as a creative act and as a political act, is an effort to read the world and the word. Now it is no longer possible to have the text without context. (p. 43)

Freire and Macedo significantly enrich our understanding of literacy by helping us essentially to see it as socially constructed forms of cultural and communicative practices. Viewing literacy in this manner shifts our attention away from the dominant concept of literacy as the ability to read, write, and speak. Instead, by demonstrating how culturally different minorities use oral and literate modes to inter- 
act in the home, community, and classroom, they bring us closer to understanding literacy as a form of cultural politics.

Stressing that the language of subordinate groups is as linguistically rule-governed and sophisticated as the language of dominant groups, Freire notes: "What they [sociolinguists] show is that, scientifically, all languages are valid, systematic, rule-governed systems, and that the inferiority/superiority distinction is a social phenomenon" (p. 53). However, Freire and Macedo are quick to point out that regardless of the equality of language forms, the notion that cultures are simply different but equal is a gross mystification perpetuated by dominant theories of literacy. We are constantly reminded throughout the book that subordinate groups are located within social relations marked by the unequal distribution of power. Since the dominant culture generally functions in the interests of certain groups over others on the basis of race, age, class, and gender, subordinate groups are often denied access to the power, knowledge, and resources that could allow them to become critically literate. Macedo draws a parallel between this aspect of American society and public schooling, remarking that "When curriculum designers ignore important variables such as social-class differences, when they ignore the incorporation of the subordinate cultures' values in the curriculum, and when they refuse to accept and legitimize the students' language, their actions point to . . . inflexibility, insensitivity, and rigidity. . ." (p. 124). Linguistic- and racial-minority students are the hardest hit by the educational system, which has systematically evaluated their school performance and revealed it to be inferior to that of mainstream students in English. This has been done, however, without fully considering "their struggle against racism, educational tracking, and the systematic negation of their histories" (p. 154). This dilemma has been brought about, according to Freire and Macedo, because of a general failure by American educators to link school performance to the structural relations of the wider society:

. . . Educators, including the present secretary of education, William J. Bennett, fail to understand that it is through multiple discourses that students generate meaning of their everyday social contexts. Without understanding the meaning of their immediate social reality, it is most difficult to comprehend their relations with the wider society. (p. 154)

Mainstream approaches to literacy, which too often concentrate on the sheer mechanics of reading and writing, fail to take seriously enough the learner's sociocultural context - his or her own social reality - in which meaning is actively constructed. All too frequently the social reality of the learner is assumed to correspond to reality as it is defined by the dominant culture - to what Freire refers to as the "schooling class." 13 Speaking on this issue, Freire comments:

13 Donald, Language, Literacy and Schooling. See also Henry A. Giroux and Peter McLaren, "Teacher Education and the Politics of Democratic Life: Beyond the Reagan Agenda in the Era of 'Good Times,' " in Schools as Conduits: Educational Policymaking During the Reagan Years, ed. Carol Camp Yeakey and Gladys Styles Johnson (New York: Praeger, in press); Peter McLaren, "No Light But Rather Darkness Visible: Language and the Politics of Criticism," Curriculum Inquiry, in press. It should be made clear here that even the more radical theories of resistance, while romanticizing the culture of the poor without considering how it also has been colonized by the dominant ideology replete with its differences and contradictions, have failed to analyze how power is lived in everyday, practical experience. Theories of resistance often miss the connection between literacy and sexuality and the manner in which sexual domination reproduced as literacy is lived through the gendered practices of the family and society (Rockhill, "Gender, Language and the Politics of Literacy"; see also Rockhill, "Literacy as Threat/Desire"). 
This large number of people [in the United States] who do not read and write and who were expelled from school do not represent a failure of the schooling class; their expulsion reveals the triumph of the schooling class. In fact, this misreading of responsibility reflects the schools' hidden curriculum. (p. 121)

Freire goes on to interpret the so-called "illiteracy" among students as their reaction "to a curriculum and other material conditions in schools that negate their histories, cultures, and day-to-day experiences" (p. 121). He explains that illiteracy, as it is treated within the dominant perspective, refers to reading and writing skills which are inadequate to the task of carrying out efficiently and productively the actions required by dominant social groups to secure established social relations of production. Potential labor power is therefore wasted among "illiterates," and this adversely affects the economic and technological expansion of the wider society. Freire and Macedo consider this dominant view of illiteracy to pose a real threat to democracy, since the possibilities for making choices and intervening in reality are all but foreclosed when the social, political, and economic consequences of reading and writing are tied to the logic of the marketplace. The dominant model of literacy not only ignores the learner's creative capacity but also encourages a passive acceptance of the status quo. On the contrary, critical literacy always implies a political reading of the world, accompanied by a transformation of the oppressive relations which constitute that world. In a powerfully moving response to a question posed by Macedo, Freire states:

Your question reminds me of my dream of a different society, one in which saying
the word is a fundamental right and not merely a habit, in which saying the word
is the right to become part of the decision to transform the world. To read the
word that one says in this perspective presupposes the reinvention of today's soci-
ety. The reinvention of society, on the other hand, requires the reinvention of
power. (p. 55)

\section{Critical Literacy and the Canon}

When placed beside Freire and Macedo's conception of critical literacy, the flaws in the prescriptivists' positions become more obvious. For instance, the arguments for the establishment of a literary canon fail to address the ways in which dominant texts constitute an articulation of the societies that produced them. That is, those in favor of teaching a canon of prescribed works rarely draw attention to the importance of understanding the ideological dimensions of such works - an understanding which challenges the interests and values of the societies in which these works were generated. Read collectively, the arguments of the prescriptivists sound like a rallying cry to bring back a bogus past in which teachers were required to act "with stature" and students slavishly venerated school escutcheons, crests, cups, honor boards, badges, pennants, and school ties - the standard supporting insignia during the days when Mr. Gradgrind cracked you on the knuckles for failing to memorize your ten lines of Cicero.

Strands of elite Western culture, those that encode primarily the triumph of White males, constitute a significant portion of this canon. Culture in this view is presented as a sacred pool of cultural information - a cultural index, if you will - the mastery of which will usher the student into the forum of national literacy. While prescriptivists consider prior knowledge important, just as pluralists do, prescriptivists tend not to acknowledge the social contexts which shape this 
prior knowledge. Prescriptivists who favor the development of a national canon of literary works in higher education are more likely to identify with Bloom's position over that of Hirsch. Bloom's perspective tends to naturalize among subordinate groups the idea that the classic works of literature are not only constitutive of a high status incompatible with the social standing of those groups but partake of a certain quality of understanding for the most part inaccessible to their "closed minds"; such high-status knowledge is therefore better off left to be consumed by those students who have "earned" entrance to the top Ivy League schools. In a similar fashion, Bloom's perspective reinforces the idea among privileged groups that the classics bear a natural allegiance to their more culturally nourished, inherently superior, and vastly more "open" minds.

The most compelling argument in favor of this canon is its harkening back to the civilizing influence of the Great Tradition, much like the clarion call sounded by the Leavisites throughout the pages of their journal, Scrutiny, and in their valorization of the works of Austen, Eliot, James, Conrad, and Lawrence. Such a yearning for past virtue may produce a temporary surge of adrenalin in those who "man" the ivory towers of contemporary America, but ultimately rings hollow for those who hold that great literature should have emancipatory social consequences and be able to empower individuals to redress the structural inecualities that plague the social order. The argument which claims that a return to the Great Tradition will re-civilize illiterate America and purge it of the dross accumulated by the current cultural barbarism is contradicted by the pretensions which structure its own discourse-pretensions which lead us to believe that literature can transcend the forces of history, material relations, and the multiplicity of responses that it evokes in its readers. In Bloom's quest for a literary canon, knowledge is monumentalized, sanctified, and held up self-consciously and reverently as the guardian of those souls seeking virtue and those minds in search of eternal wisdom. Bloom's agenda for educational reform asserts the contradiction between what is and what should be based on a romantic distortion of what once was; on the other hand, Freire and Macedo build their case for educational reform by seeking utopian possibilities within the social forms of the present historical juncture based on what could be, while at the same time challenging the oppressive characteristics of those social forms.

This literary canon will always remain a form of cultural invasion as long as the interests which inform it are not uncovered to reveal their political locus, their real social and ideological weight. As long as knowledge is posited as eternal wisdom, educators will be discouraged from becoming self-reflective about the internal assumptions which legitimate such knowledge. This canon also implies a pedagogy of submission. From the prescriptivists' perspective, little is relevant outside the strictures of the required curriculum. From a Freirean position, this approach extinguishes independent thinking and critical human action. We are left with a traditional discourse dressed up for the current generation and prescribed without a precise knowledge of the rules of its own formation.

While prescriptivists argue that the cultural heritage of the United States should be taken seriously, they do so in a way that conceals its socially derivative status and cloaks the selective interests which this inherited agenda serves in the mantle of eternal principles of justice, equality, and fraternity. They fail to acknowledge that ideology shadows the steps of all knowledge-inherited or not. In other words, they fail to take into account the relationship between knowledge and power. This failing is readily apparent in the epistemological premises set forth 
in the work of E. D. Hirsch. Here knowledge is equivalent to sharing a body of information, and teaching is reduced to transmitting this information. Hirsch's view of how students become culturally literate reifies culture as a museum of events frozen in time and shrouded in the classical quest for permanence. Pedagogy in this view is reduced to sharing the "facts," and the role of the teacher becomes that of the curator of the national heritage. Rarely are attempts made to destabilize the reified conceptualizations of cultural "facts" or to defamiliarize the domesticating myths which often serve to legitimate existing relations of power and privilege in the larger social order. Culture in this view becomes essentialized outside the forces of power and history rather than analyzed as a fluid and contestatory site where power works to favor certain forms of knowledge and where a multiplicity of discourses war for dominance. In order to draw attention to this relationship between knowledge and power, Freire poses the following questions: "in favor of whom and what (and thus against whom and what) do we promote education? And in favor of whom and what do we develop political activity?" (p. 38). On this matter, Freire is unwavering:

Only those who have power . . . can define what is correct or incorrect. Only those who have power can decide what constitutes intellectualism. Once the intellectual parameters are set, those who want to be considered intellectuals must meet the requirements of the profile dictated by the elite class. To be intellectual one must do exactly what those with the power to define intellectualism do. (p. 122)

Hirsch's argument for the cognitive superiority of standard English, which attributes intellectual advancement to the formal structure of the symbol system, steadfastly ignores the social situatedness and ideological nature of language. That is, he avoids attending to the cultural and political significance attached to mastering dominant discourses. Macedo points out that different English dialects, such as Black English, "decode different world views" (p. 127) and that "the semantic value of specific lexical items belonging to black English differs radically, in some cases, from the reading derived from the standard, dominant dialect" (p. 127). While affirming Black English does not, in Freire's words, "preclude the need to acquire proficiency in the linguistic code of the dominant group," it does mean that Black English can become, in Macedo's terms, "a powerful tool demystifying the distorted reality prepackaged for them by the dominant curriculum" (p. 128). Whereas Hirsch believes the information processing of standard English is necessary to be able to transcend cultural and historical contingencies, Freire and $\mathrm{Ma}-$ cedo understand literacy to inhere in the sociopolitical context of the subjects themselves. Freire makes this clear when he suggests that educators in the United States "need to use their students' cultural universe as a point of departure, enabling students to recognize themselves as possessing a specific and important cultural identity" (p. 127). In a similiar manner, works of literature cannot be detached from their social origins. ${ }^{14}$ What Freire and Macedo take seriously, and

\footnotetext{
${ }^{14}$ The problem, as some critics see it, is not with the idea of preserving our cultural heritage, a surely laudable end in itself, but with preserving a heritage which is too homogeneous and narrow in scope. As John Sisk notes: "We are confronted once again with the question of whether it is more characteristic of Americans to fear that they are losing their heritage, or to fear that the heritage they are supposed to be afraid of losing has been too narrowly constructed." See John P. Sisk, "What Is Necessary," Salmagundi, 72 (Fall 1986), 145.

The narrowness of vision inscribed in this view of the canon stems, in part, from the uncritical assumption that humanistic texts are - and should be-essentially ideologically neutral. Robert Scholes
} 
prescriptivists do not, is the means by which history has granted certain texts canonical status and excluded the local cultural canons of subjugated groups. In other words, history is often written by the powerful, and the literary texts most likely to be found on a list of prescribed works are those which rarely threaten the social and economic stability of the established order. Works by writers who have been marginalized because they happen to be female or members of minority groups, or works that constitute political perspectives inhospitable to the dominant culture, are not likely to be admitted to the national canon. The text, from the perspective of a critical literacy, never ceases to be open to the world or to history. Even purportedly high culture is shot through with history and steeped in the meanings that the dominant culture has given it. ${ }^{15}$

Any perspective which advocates the incontestable superiority of the Great Books, in which teachers are required to transmit the praiseworthy aspects of our cultural heritage, is inherently problematic from a Freirean standpoint. Such a strident, demanding manifesto rests on the neoclassical notion that culture exists as a receptacle for ideas and somehow "contains" knowledge (as distinct from the concept that knowledge is socially constructed). Granted, to deny students access to the great intellectual and aesthetic works our culture has to offer is a grave injustice. But it is important to recognize that great works do not speak for themselves. To claim that they do is to argue erroneously that they transcend history and the contextual specificity of the discourses which generated them and to additionally

criticizes William Bennett for being upset that the humanities are sometimes used by educators to present certain social perspectives. Scholes writes:

He [Bennett] wants the classroom to be exciting and value free, and he believes the great humanistic texts to be exciting and value free also, as if Dante, Virgil, Karl Marx and T. S. Eliot (to name four from his list of classics) were ideological innocents, sharing a common humanistic view of the world. Mr. Bennett is not innocent either, and nowhere is this more apparent than in his taking the hotly debated question of the ideological component of humanistic texts as a matter already settled to the effect that they have none-or if they do it should not influence our regard for them. (Robert Scholes, "Aiming a Canon at the Curriculum," Salmagundi, 72 [Fall 1986], 110.)

In his call for a return to a classics-oriented core curriculum for the universities, Bennett has recently criticized scholars who are trying to include works by women and members of minority groups into the canon as "trendy lightweights." (See The Chronicle of Higher Education, February 17, 1988, pp. 1, 16.) Of course, Bennett's concept of the canon, as Rockhill points out, is also linked to his drive to establish "moral literacy" as a fundamental teaching of schools and colleges. The argument being levelled at the exponents of the illiberal canon by critics such as Scholes is not so much a greater call for more relevance (for example, the inclusion of folk culture or popular culture) as much as it is a call for rendering official culture problematic; that is, they are concerned not with the canon itself (although they would like to see it broadened to include works by subjugated groups such as women and minority writers) but with the pedagogical strategy used to teach the canon. See reference to Bennett in the New York Times, September 30,1986, p. 25, as cited in Rockhill, "Gender, Language and the Politics of Literacy," p. 157.

${ }^{15}$ Patricia Bizzell, "Arguing about Literacy," College English, 50 (1988), 141-153. According to Bizzell, Hirsch believes that the academic canon "has been granted by history the power to transcend and hence to control local canons" (p. 147); furthermore, "Hirsch assumes that history has granted the academic canon the right to exercise this power over other cultures, through establishing canonical ways of thinking and of using language, canonical values, verbal styles, and mindsets as the 'most important' to our national culture" (p. 147). In adopting a deterministic view of history, Hirsch's use of the term "history" is reduced to "a cover term, concealing not only the process whereby certain texts achieve canonical status but also the process whereby attitudes towards the very existence of any canon, and its function in society, become ingrained" (p. 148). 
argue that these works deserve to be universally consumed regardless of the particular characteristics of the students whom the curriculum is intended to serve. The prescriptivists do not seriously consider the question of whose interests, values, and stories are affirmed and legitimated by the canon. From Freire and Macedo's point of view, such an approach to cultural literacy is sectarian and paternalistic, and represents a form of cultural domination in which the socially constitutive nature of both readers and texts is all but ignored. This non-ideological view of literacy, which presents knowledge as inexorably given and self-justified by its academic valorization through the ages, becomes a "magical view" of the written word based on its status as ideologically uncontaminated information. Freire underscores this position in the following passage:

To avoid misinterpretation of what I'm saying, it is important to stress that my criticism of the magical view of the written word does not mean that I take an irresponsible position on the obligation we all have - teachers and students - to read the classic literature in a given field seriously in order to make the texts our own and to create the intellectual discipline without which our practice as teachers and students is not viable. (p. 34)

What is disquieting in the prescriptivists' position is that the high-status knowledge of classic literary works becomes the only kind of knowledge deemed immutable and sacred enough to warrant its inclusion in the curriculum. The subjugated knowledge of economically disadvantaged groups, women, and minorities is insistently denigrated in the prescriptivists' view of what should be taught, how it should be taught, and to whom. ${ }^{16}$ For instance, in Bloom's sanctified universe it would be scandalous to include in the pantheon of great literary masters the figures of Richard Wright, James Baldwin, Ralph Ellison, or Alice Walker - writers whose brilliant vernacular ascriptions, writing "degree zero," and carnivalesque discourse have broken down the time and space of the conventional aesthetic theory of the "white male Brahmins." ${ }^{17}$ It is here that the fixity of classical thought and the exclusionary practices of racist elites impose interpretive shackles on the literary possibilities of the "other," which include writers who are Black, female, or belong to minority groups. Addressing the matter of elitism, Freire writes:

${ }^{16}$ According to Elizabeth Fox-Genovese, the canon is profoundly bound by gender, race, and class. At the same time, she argues that some kind of canon is necessary, if not inevitable, and the present one need not be completely rewritten. If social transformation is to take place, two things must happen. First, the established canon must be reinterpreted from the perspectives of history, race, class, and gender. Second, the canon must be expanded. She writes:

We can, with little difficulty, select texts by standard canonical authors that address issues of gender, race, and class. We can, in the spirit of contemporary theory, view teaching as an exercise in hermeneutics: We reread our texts from the perspective of contemporary concerns. In addition, we can transform the entire focus of conventional courses by the themes we select. . . . Modern criticism reminds us that even a reactionary text may raise contradictions that it imperfectly resolves. (Fox-Genovese, "The Claims of a Common Culture: Gender, Race, Class and the Canon," Salmagundi, 72 [Fall 1986], 141-142.)

For an excellent critical analysis of some "great books," see Terry Eagleton, William Shakespeare (New York: Basil Blackwell, 1986). Eagleton is able to show how the search for identity undertaken by many of Shakespeare's characters is historically bound up with the exchange economy of commodity production.

${ }^{17}$ Houston A. Baker, Jr., Blues, Ideology, and Afro-American Literature: A Vernacular Theory (Chicago: University of Chicago Press, 1984), pp. 150-151. Baker's work constitutes a brilliant discussion of Afro-American culture and literary history, particularly in relation to Afro-American expressive culture. 
From the authoritarian, elitist, reactionary point of view, the people's incompetence is almost natural. The people need to be defended because they are incapable of thinking clearly, incapable of abstracting, knowing, and creating; they are eternally "of lesser value"; and their ideas are permanently labeled exotic. Popular knowledge does not exist. The authentic manifestations of the culture of the people do not exist. The memory. of their struggles needs to be forgotten, or those struggles related in a different way; the "proverbial inculture" of the people does not permit them to participate actively in the constant reinvention of their society.

(p. 44)

The issue here is not necessarily to add oral literatures, minority literatures, and other noncanonical works to the canon, but to study canonical and noncanonical works comparatively, with an eye to the historical and ideological reasons why some works are canonized and others are not and the interests such works promote within power and knowledge junctures constructed in wider institutional and social contexts.

The disdain of many prescriptivists (especially those influenced by Bloom) for the prosaic plane of the popular or "vulgar" offers little room for a critical understanding of more contemporary cultural formations, such as radio, video, and film genres, and how they operate in today's world to help construct student subjectivities. But it is precisely in the understanding of how the everyday and the popular intersect with the larger social order that the success of critical literacy rests. That is, for critical literacy to be effective, it must be embedded in the concrete conditions of the students themselves. ${ }^{18}$ For instance, to ignore or dismiss as barbaric popular cultural forms such as rock music or music videos is to erroneously deny the relationships which obtain among popular culture, student experience, and the construction of ideological codes governing reader reception. Further, it is to willfully dismiss as unimportant or insignificant the connection between student alienation from classical texts and new narrative forms currently being constructed in the domain of the popular. From this vantage point, the idea of a national canon of literary works reeks with intellectual elitism, ${ }^{19}$ constitutes an "anti-dialogical" theory of action, and encourages educators to ignore both popular culture and the

18 To become literate is always to engage the world as a continuous, deep penetration of cultural and historical experience. Becoming literate can never occur in antiseptic isolation from the world. Furthermore, criticisms of mainstream literacy programs in schools have been based on the charge that they have been reduced to a process which encourages students to learn sanitized facts stripped of ambiguity and contradiction and therefore do not necessarily lead students to be critically minded or acquire a significant amount of social, political, or intellectual empowerment. As Mikhail Bakhtin has so presciently shown us, becoming literate is a form of "philosophical anthropology" in which literacy becomes the most empowering precisely when it becomes the most social and contextually interactive. See Mikhail Bakhtin, Speech Genres and Other Late Essays (Austin: University of Texas Press, 1986).

19 Terry Eagleton reflects the perspective of Freire and Macedo by drawing attention to the ideological formations into which works of literature are inserted and valorized. He writes:

Texts are constituted as "literary," in the normative sense, because they are judged to exemplify certain peculiar uses of language, to evoke certain significant responses, to communicate certain valued meanings. . . . Literature helps to secure our present social relations, not in the first place by apologizing for capitalism, but by being Literature. It is already relevant to class divisions that there exists a privileged body of discourse, sharply demarcated from "popular" modes, enshrined and disseminated, as valuable cultural capital, to future members of the dominant social class. . . . To construct . . . a tradition demands a practice which will select, reconstitute, process and "correct" certain pieces of writing so that they compose an imaginary unity, one responsive to the demands of a ruling ideology. (Eagleton, Critical Quarterly, 20 [1978], 66) 
cultural integrity of the student. Simply to attempt to inculcate a set of eternal virtues in students by transmitting a prescribed body of so-called wisdom - as if such wisdom transcends social contexts and the local ideological agendas to which they give rise - is virtually to anesthetize consciousness in Freirean terms; it is to adapt students to become pliable and docile members of the world as it exists rather than as it might become. ${ }^{20}$ Rather than encouraging students to become ambassadors of the status quo, Freire and Macedo invite them to take part in a critically active transformation of the larger social order. Once the student is able to "depedestal" the literary tradition of Great Works, he or she can begin to gauge the importance of popular texts and "local knowledge" in establishing the grounds for a critical literacy. From a Freirean perspective, Bloom's agenda for educational reform is coopted by the very conditions it attempts to analyze because it does not challenge the premises which structure the logic of its own mode of inquiry.

Freire and Macedo argue against the "banking" form of pedagogy often implied in prescriptivist models of cultural literacy. The authors argue that simply to deposit into the memory banks of students tidings from the most esteemed minds of Western culture inhibits the development of a critical consciousness. ${ }^{21}$ Freire makes this position clear in the following remarks:

He who "immobilizes" knowledge and transfers it to students, whether in primary schools or universities; he who bears only the echo of his own words, in a kind of oral narcissism; he who believes it insolvent for the working class to recover its rights; he who thinks the working class is uncultured and incompetent and, thus, needs to be liberated from top to bottom - this type of educator does not really have anything to do with freedom or democracy. On the contrary, he who acts and thinks this way, consciously or unconsciously, helps to preserve the authoritarian structures. (p. 40)

Brushing against the grain of the prescriptivists' quest for a literary canon is Freire and Macedo's rallying cry to make the content of the curriculum relevant to the transformation of the sociopolitical reality and life situations of learners.

\footnotetext{
${ }^{20}$ Radical critics of this "value neutral" position pose the question of who decides what text will be chosen, and which individuals will be selected to engage this privileged text. Hirsch, Bloom, and Bennett fail, in these critics' view, to link the concept of cultural literacy to the empowerment of a language of public life, one that resonates with the lived experiences of a heterogeneous population. See Henry A. Giroux, Schooling and the Struggle for Public Life: Critical Pedagogy in the Modern Age (Minneapolis: University of Minnesota Press, in press). See also Peter McLaren, "Foreword: Critical Theory and the Meaning of Hope," in Teachers as Intellectuals: Toward a Pedagogy of Practical Learning by Henry A. Giroux (South Hadley, MA: Bergin \& Garvey, in press); Peter McLaren, "Postmodernism and the Death of Politics: A Brazilian Reprieve," Educational Theory, 36 (1986), 389-401; Peter McLaren, Life in Schools: An Introduction to Critical Pedagogy in the Social Foundations of Education (New York: Longman, in press); and Laurie McDade, "The Deficit-Difference Debate: Theoretical Smokescreen for a Conservative Ambush," paper presented at the meeting of the Ohio Valley Philosophy of Education Society, Lexington, Kentucky, October 16, 1987.

${ }^{21}$ Critics of this view of cultural transmission argue against the position that the meanings of great works are forever fixed, and assert instead that the very act of reading a text subjects the reader to the textual strategies of the writing in question and its attempt to position readers as subjects and to extend to them its values and view of the world. Feminist critics of this version of cultural literacy argue that it is possible to trace the formative power of patriarchal, class, and racial interests not just in modes of reading and the constitution of the canon, but in what is available to be read at all. See Chris Weedon, Feminist Practice and Poststructuralist Theory (New York: Basil Blackwell, 1987), pp. 169170. We gain a key insight into Hirsch's epistemology and pedagogy from his early work, Validity in Interpretation (New Haven: Yale University Press, 1967), which is concerned with how meaning is
} 
They assert that students become active, knowing subjects not by being fed cultural information but through the process of conscientization, that is, through learning to perceive social, political, and economic contradictions in the social world in order to transform one's lived social relations and the larger, macrosocial order. ${ }^{22}$ Freire and Macedo know that their primary matrix as educators is coextensive not with the logic of capitalism but with the suffering of the oppressed. A critical literacy situates itself in the intersection of language, culture, power, and history - the nexus in which the subjectivities of students are formed through incorporation, accommodation, and contestation. The struggle is one that involves their history, their language, and their culture, and the pedagogical implications are such that students are given access to a critical discourse or are conditioned to accept the familiar and self-evident as the inevitable. Worse still, they are denied a

communicated. According to Hirsch, meanings can be shared and truth thus preserved becaus objects of understanding have a unitary, fixed, or ideal essence. Meanings are determinate, possess boundaries and self-identity, and can be directly transferred from the consciousness of one person to that of another. This makes it possible for a number of persons to hold the same meaning or to share similar interpretations of events. In Hirsch's view, individuals are the authors of their own meanings: they claim actual ownership over their meanings. Thus, people can share in other people's meanings quite readily. Meanings are stable and determinant and escape the contingency and indeterminacy of individual consciousness. In this account, Hirsch's epistemology is very traditional and stands in direct opposition to more recent influences within the domain of critical pedagogy made by deconstruction and postmodern social theory. For Hirsch, meanings can be willed by individuals who fix the contexts of their messages. To share somebody's meaning, we must become subservient to the will or unified with the intentionality of the author of that meaning. In contrast, deconstruction attacks the concept of rational volition and the law of identity, as do recent manifestations of poststructuralism, continental philosophy, and postfeminism. The concepts of the "decentered subject" and the radical discontinuity and fragmentation of the ideal object - which are taken seriously in these recent theories of discourse - have important implications for developing a pedagogy of literacy. By purging concepts of their unequivocal metaphysical foundations (foundations which Hirsch seeks to preserve at all costs), the concepts of truth and meaning become, in the poststructuralist view, contingent on the contexts of culture, language, history, and the material forces of production. This formulation of meaning shatters the concept of the ideal wholeness of meaning which undergirds the epistemology of Hirsch. Freire and Macedo, in contrast to Hirsch, are in partial sympathy with the poststructuralist position on meaning in that they recognize its contingency and ideological dimensions, which they argue must be probed by a radical doubt. Freire and Macedo are not denying that meanings may be intended and communicated by an author; rather, they suggest that meanings cannot be essentialized outside of the experiences readers bring to those meanings, the cultural contexts in which those meanings are generated, and the historical juncture in which text and reader meet. Language, in this view, is structurally open and may be detached from the intention of its user. That is, there always exists the possibility that language may position both author and reader ideologically within relations of power according to the contextual specificities of race, class, and gender. These contexts must be understood and addressed if we are to become critically literate. Hirsch, however, assumes that meanings, as fixed and shareable, may be transferred from text to reader independent of the messy web of ideological ingredients that might throw doubt on or alter the substance of what the author of the text intended. Freire and Macedo do not assume that meanings can be deposited in readers' minds as fixed essences, for in their view, meanings inscribed by language are always subject to the contextual specificity of their generation and reception. Meanings, in other words, are always dependent upon who interprets them and the experiences brought to the act of interpretation. For instance, neither women's nor men's experiences as readers are homogeneous. The same is true for White women and Black women, White men and Black men, middle-class students and economically disenfranchised students. For a discussion of Hirsch's epistemology in relation to the theories of Wittgenstein and Derrida, see Henry Staten, Wittgenstein and Derrida (Lincoln: University of Nebraska Press, 1984), pp. 139-145.

22 Adrian Bennett has enlarged our understanding of the politics of literacy by recognizing that students do not simply communicate sociolinguistically through various "participant structures" (that is, restricted or elaborate codes, oral or literate modes, literary practices), but also engage in what he 
voice with which to be present in the world; they are made invisible to history and rendered powerless to shape it. Critical literacy in Freire's terms is a transgressive act of reading the word and the world that embodies an attack on dominant signifying practices and calls into question the moribund scruples of the bourgeois humanist text, placing them in a wider social and temporal context. Any Freirean approach to the canon must therefore make clear the fact that texts are products of the interests that inform dominant social and cultural groups, and that educators must assuredly probe the canon for what it does not say-for its "structured silences," its "present absences," its exclusionary politics - as well as for what it actually does say. Freire and Macedo deny a privileged status to claims that knowledge finds its quintessential expression in classical discourse. Rather than arguing for a cultural canon of inherited texts, Freire advocates the creation of what he calls the "popular library." A popular library would serve as a cultural aid and learning center "and not just a silent depository of books" (p. 45). The purpose of constructing a network of popular libraries would be to "stimulate educational or popular culture programs (in the fields of adult literacy, health education, research, theatre, technical training, and religion), programs that respond to the popular demands provoked by an effort of the popular culture" (p. 46). Freire and Macedo situate learning in the terrain of the popular, wherein it becomes an active process of dialogical engagement between teachers and students. What emerges from a collaborative pedagogy between teachers and students is a knowledge that is generated dialectically from cultural ingredients that could be - and often areboth canonical and non-canonical. The idea of the popular library as set forth by Freire differs from the common cultural index advocated by Hirsch, in that Hirsch pays little attention to the sociopolitical context which frames the act of knowing. Also lacking in Hirsch's work is an understanding of the power/knowledge junctures in which pedagogy is practiced and learning takes place. If, on the other hand, we are to make a clear distinction between cultural literacy as set forth by prescriptivists influenced by Bloom, and critical literacy as advocated by Freire and Macedo, we would have to say that the former position transforms high culture into a form of currency made up of essentially inert ideas culled from the selective tradition of classic literature, which are to be deposited among the uncultured as timeless truths. The Freirean position, on the other hand, invites an understanding of culture as the lived relation of individuals to historical conditions and material circumstances. Literacy is something that grows out of these lived relations as part of the dynamics of everyday life.

calls "participant struggles." Bennett uses this term to underscore his observation that students frequently question the contradictions inherent in the ideologies voiced by the teacher, very often without recognizing it. Bennett formulates illiteracy as an act of refusal, one in which students engage in a struggle over the ways in which conflicting interpretations of the social world are considered valid by both students and teachers alike. In this view, becoming literate, or refusing to be literate, involves a sociopolitical struggle over whether the teacher's interpretation of the world is to prevail and over how much serious accord will be given the voices of the students. Acquiring literacy is thus fundamentally linked to the model of social life students and teachers use to articulate their ideas in their interaction with each other, and to what degree these models are tied to specific social, political, and economic interests. The crucial question that is immediately raised by this insight is: What are the social conditions that construct the framework out of which students and teachers "read" particular forms of knowledge? See Adrian T. Bennett, The Struggle for Voice: Literacy and Consciousness in an East Harlem School (South Hadley, MA: Bergin \& Garvey, in press). See also Peter McLaren, Schooling as a Ritual Performance (New York: Routledge \& Kegan Paul, 1986). 
We could thus say that literacy in Freire and Macedo's view is language that is enfleshed; that is, language consisting of many tissues of meaning which have been constructed not only through a rational engagement with the cultural world but through an engagement in this world by the learner's own body. All discourse, spoken or written, is caught in the net of the body. Literacy, therefore, is an act of the body. Language not only organizes and legitimates our world on a rational basis but resonates with and constructs our "felt" needs, desires, and values. Literacy divorced from the lived situations of the learner is a form of disembodied knowledge, severed from the interests, values, and concerns of the learner. What makes literacy "critical," in Freire and Macedo's view, is its ability to make the learner aware of how relations of power, institutional structures, and models of representation work on and through the learner's mind and body to keep him or her powerless, imprisoned in a culture of silence.

In fact, a critical perspective demands that the very ideological process of language construction itself be interrogated. Individually and collectively we produce language, yet the social reality which language constructs, conveys, and objectifies also produces us, its users, by providing us with subject positions from which to speak and consequently from which to be spoken to. As a social practice, language is constituted by material and social reality which informs both its codes and the subjectivities of its users. Language provides us with tools with which to shape meaning from a universe of indeterminate signs; yet the very tools we use to cobble meaning have been fired in the same crucible of historical and discursive struggle from which we have forged the linguistic weapons for our crusades of cultural domination.

\section{Conclusion}

Freire and Macedo argue that the fundamental structural principle of a pedagogy of critical literacy is the need for pedagogical practices that will provide students with the opportunity to use their own reality, including the language these students bring into the classroom, as the basis of literacy. However, Freire and Macedo also make clear that while educators "should never allow the students' voice to be silenced by a distorted legitimation of the standard language" (p. 152), they should, nonetheless, "understand the value of mastering the standard dominant language of the wider society" (p. 152). This perspective goes directly against the claim made by William Bennett that only English "will ensure that local schools will succeed in teaching non-English-speaking students English so that they will [enjoy] access to the opportunities of the American society" (p. 155). Bennett's claim also contradicts the theoretical and research literature which argues that literacy skills acquired through linguistic interaction in one language (such as Spanish) play a major role in making input in another language (such as English) comprehensible. ${ }^{23}$

Mainstream approaches to pedagogy, as advocated by Bennett and others, are unable to develop a critical literacy because, in Freire's view, they violate the basic

\footnotetext{
${ }^{23}$ See S. Krashen and D. Biber, Bilingual Education in California, report prepared for the California Association for Bilingual Education, 1987. See also Jim Cummins, Bilingualism and Special Education: Issues in Assessment and Pedagogy (Clevedon, Eng.: Multilingual Matters, 1984, copublished in the United States by College-Hill Press, San Diego); Jim Cummins, "Empowering Minority Students: A Framework for Intervention," Harvard Educational Review, 56 (1986), 18-36; and Jim Cummins, Empowering Minority Students (Albany: State University of New York Press, in press).
} 
structuring principle of emancipatory pedagogy, which focuses on empowerment. Empowerment in this instance refers to the process of helping students acquire modes of critical analysis which will provide them with both the theoretical ability and moral incentive to transform, rather than merely serve, the dominant social order. In any pedagogy of critical literacy, certain values must be made concrete. These include the values of "solidarity, social responsibility, creative discipline in the service of the common good, vigilance, and critical spirit" (p. 156), all of which are to be linked pedagogically to the overall goal of "national reconstruction." Freire and Macedo understand that, as a form of political empowerment, critical literacy represents both a theory of pedagogy and a pedagogy of theory. ${ }^{24}$ It constitutes a theory of pedagogy in that students are taught to analyze critically how culture functions within asymmetrical relations of power to give certain groups an advantage over others on the basis of race, class, and gender. It serves as a pedagogy of theory because it recognizes that only when theory transforms itself into praxis and engages in a project of possibility does it truly enter the world of emancipatory teaching. That is, only when theory becomes transformed into a political act can it realize its socially transformative potential.

Freire and Macedo read the problem of illiteracy in American education primarily as one of resistance to a dehumanizing and alienating culture of silence, as well as an act of self-affirmation. Ironically, this perspective turns the act of resistance into an exercise of critical literacy:

The many people who pass through school and come out illiterate because they resisted and refused to read the dominant word are representative of self-affirmation. This self-affirmation is, from another point of view, a process of literacy in the normal, global sense of the term. That is, the refusal to read the word chosen by the teacher is the realization on the part of the student that he or she is making a decision not to accept what is perceived as violating his or her world. (p. 123)

For Americans besieged by the relentless logic of consumerism and privatization, it is no wonder that illiteracy thrives as a means of resistance-of refusing to be part of the cultural nightmare. What is needed to meet the crisis of literacy is a critical theory that frames reading, writing, and the performance of public discourse in terms of moral and political decisionmaking. Literacy in this view is not linked to learning to read advertisements in order to become a better consumer, to escaping into the pages of a romance novel or spy thriller, or to engaging a classical work of literature in order to learn the meaning of "the good" or "the true" so that one can live "the virtuous life." Rather, a critical literacy links language competency to the acquisition of a public discourse in which empowered individuals are capable of critically engaging the social, political, and ethical dimensions of everyday life. To be literate in this instance means not only being able to understand and engage the world but also to be able to exercise the kind of moral courage needed to change the social order when necessary. Such a perspective of literacy astutely recognizes that language is that sociolinguistic territory in which history both rehearses its nightmares and dreams its liberating possibilities. Language may be used to affirm the voices of the marginalized and disaffected or to silence them. Critical literacy acknowledges the importance of constructing "dangerous memories"-depictions of events of human suffering and courage-

${ }^{24}$ See David Lusted, “Why Pedagogy?” Screen, 27 (1986), 4-5. 
through excavating, rescuing, and affirming the voices of those who have been silenced and marginalized by the dominant culture. In this regard, critical literacy becomes an expression of both protest and hope that leads to political action.

The solution to achieving critical literacy in the classroom rests, according to Freire, "in a full understanding of the ideological elements that generate and sustain linguistic, racial, and sex discrimination" (p. 155). Only by approaching literacy as a form of ideological critique can knowledge be made critically relevant to students and eventually lead to a reinvention of society through a transformation of the oppressive power relations which structure society. It is precisely in this emphasis on an ideological unveiling of the oppressive features of social reality that Freire and Macedo tend to repeat themselves, thereby limiting possibilities for further theoretical advancement. Too often they refrain from being explicit about the connections between critical literacy and critical pedagogy, although this link is discussed thoroughly in Giroux's preface. While the authors have argued for the importance of student experience in developing a critical pedagogy, they sometimes fail to articulate how popular culture-especially in the context of the United States-enables as well as constrains the development of student subjectivity. Consequently, the authors have neglected to build into their critical pedagogy those life-affirming dimensions of popular culture which could point to potentially liberating forms of social relations, of ways to create meaning, and of ways of representing ourselves, our relations to others, and our relation to the environment in short, possibilities not yet realized. This criticism should not, however, detract from the overwhelming strength and brilliance of this book.

Some readers of Literacy: Reading the Word and the World may be disappointed by its lack of a technically articulated model of educational change. This criticism has been anticipated and rejected outright by Freire and Macedo in one of their dialogues. Making very clear that he disdains "texts that primarily give recipes," Freire announces his "[refusal] to write such texts, because [his] political convictions are opposed to the ideology that feeds such domestication of the mind" (p. 134). While some readers may view this as a deliberate attempt to avoid being pinned down theoretically or perhaps even pedagogically, Freire would consider such criticism to be consistent with that aspect of North American ideology which reveres the logic of quick fixes. This is the same logic that, when embodied by educators, shrinks their capacity to comprehend critically the contextual conditions of Freire's own work and to investigate these conditions in their own classrooms. The tacit injunction, "don't criticize something unless you have a blueprint of the solution," seeks to freeze knowledge in its instrumental moment, refuses to address the dialectical tension between theory and practice, and refrains from acknowledging the provisional nature of truth itself. Those more familiar with or sympathetic towards Freire's work will clearly see the redemptive logic in Freire's idea that education is primarily about problem-posing rather than answer-giving. Once old problems have been resolved, new problems must be formulated. Freire and Macedo implicitly recognize that the struggle over knowledge is one that can never be won, or pedagogy stops. ${ }^{25}$

One of the great strengths of Literacy: Reading the Word and the World is that it refuses to reduce critical educational theory to a blueprint for educational transfor-

\footnotetext{
${ }^{25}$ See Magda Lewis and Roger I. Simon, "A Discourse Not Intended for Her: Learning and Teaching within Patriarchy," Harvard Educational Review, 56 (1986), 457-472. See also Henry A. Giroux and Roger Simon, "Ideology, Popular Culture and Pedagogy," Curriculum and Teaching (in press).
} 
mation, while at the same time challenging readers with a wide array of sensitizing constructs, critically articulated and passionately advocated, with which to rethink their educational priorities. Such an accomplishment cannot be overlooked, especially during an era in which the nature of critical knowledge is increasingly being redefined, codified for mass consumption, and imposed on teachers in a top-down fashion, irrespective of the class, gender, and racial characteristics of the vast numbers of students whom such knowledge is intended to serve. In the final instance, Freire and Macedo are able to illustrate what could be called radical hope. Radical hope is always multivocal, and carries with it a surplus of meaning. Like language, radical hope signifies beyond its own significance. Moreover, it resists the fixity of interpretation that could turn it into despair, and refuses to abandon the moral principles which generate it, thus preventing it from becoming merely "wishful thinking."

Literacy: Reading the Word and the World provides an articulate and courageous response to current questions arising from the literacy debate. It extends beyond the question of how language functions to the critical issue of how it should function. Freire and Macedo offer readers an ethical imperative designed to assist them in taking responsibility for their linguistic practices. In the final instance, Literacy: Reading the Word and the World establishes a framework for literacy which succeeds in insuring the diversity of culture and providing for the transformation of oppressive social practices. Like Bakhtin, Freire and Macedo remind us that we are all always authors, every time we speak or listen, read or write, and that ultimately we must assume the moral obligation for our dialogue with the world. ${ }^{26}$

${ }^{26}$ Gary Saul Morson, "Preface: Perhaps Bakhtin," in Bakhtin: Essays and Dialogues on His Work, ed. Gary Saul Morson (Chicago: University of Chicago Press, 1986), p. x. 
This material has been reprinted with permission of the Harvard Educational Reviewfor personal use only. Any other use, print or electronic, will require written permission from the Review. For more information, please visit www.harvardeducationalreview.org or call 1-617-495-3432.

Copyright $\odot$ by the President and Fellows of Harvard College. All rights reserved.

The Harvard Educational Reviewis an imprint of the Harvard Education Publishing Group, publishers of the Harvard Education Letter and books under the imprint Harvard Education Press. HEPG's editorial offices are located at 8 Story Street, First Floor, Cambridge, MA 02138, tel. 617-495-3432, or email to hepg@harvard.edu. 